ISSN [E]: 2477-0515 ISSN [P]: 2339-0794

DOI: 10. 10.26858/jnp.v8i2.13956

Online: https://ojs.unm.ac.id/nalar

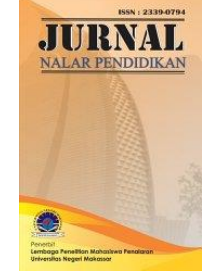

\title{
ANALISIS PENGARUH FAKTOR KECEMASAN BELAJAR DAN GAYA BELAJAR TERHADAP KEMAMPUAN PENALARAN MATEMATIS SISWA KELAS VIII DI SMP NEGERI SE-KOTA SINGARAJA
}

\author{
Ni Kadek Sudarti', I Made Candiasa ${ }^{2}$, I Nyoman Sukajaya ${ }^{3}$ \\ ${ }^{1,2,3}$ Program Studi Pendidikan Matematika, Jurusan Matematika, Universitas Pendidikan Ganesha \\ nksudarti821@gmail.com ${ }^{1}$
}

\begin{abstract}
Abstrak
Penelitian ini bertujuan untuk mendeskripsikan pengaruh langsung maupun tidak langsung antara kecemasan belajar dan gaya belajar terhadap kemampuan penalaran matematis siswa. Data pada penelitian ini adalah data kemampuan penalaran matematis yang diukur dengan tes uraian serta data kecemasan belajar dan gaya belajar yang diukur dengan kuesioner. Data dianalisis menggunakan Structural Equation Model. Hasil penelitian menunjukkan bahwa kecemasan belajar secara langsung berpengaruh negatif terhadap kemampuan penalaran matematis dengan korelasi sebesar -0,59. Sementara itu, gaya belajar secara langsung berpengaruh positif terhadap kemampuan penalaran matematis siswa dengan korelasi sebesar 0,46. Selanjutnya ditemukan bahwa kecemasan belajar dan gaya belajar juga mempengaruhi kemampuan penalaran matematis secara tidak langsung dengan koefisien korelasi sebesar -1,13. Kecemasan belajar merupakan faktor yang lebih dominan mempengaruhi kemampuan penalaran matematis yakni sebesar 34,8\%, sedangkan gaya belajar hanya sebesar $21,1 \%$. Hasil penelitian ini mengharapkan proses pembelajaran dapat meminimalisir kecemasan belajar serta meningkatkan variasi gaya belajar sehingga kemampuan penalaran matematis meningkat.
\end{abstract}

Kata Kunci : kemampuan penalaran matematis, kecemasan belajar, gaya belajar

\section{ANALYSIS THE INFLUENCE OF LEARNING ANXIETY AND LEARNING STYLE FACTORS ON MATHEMATICAL REASONING ABILITIES OF VIII GRADE STUDENTS IN JUNIOR HIGH SCHOOL SINGARAJA}

\begin{abstract}
This research aims to describe the direct and indirect effects of learning anxiety and learning styles on students' mathematical reasoning abilities. The data in this study are mathematical reasoning ability data measured by essay examination, learning anxiety and learning style data measured by questionnaires. Data were analyzed using Structural Equation Model. The results showed that learning anxiety directly had a negative effect on the ability of mathematical reasoning with a correlation of -0.59. Meanwhile, learning styles directly have a positive effect on students' mathematical reasoning abilities with a correlation of 0.46 . Furthermore, it was found that learning anxiety and learning styles also affect the ability of mathematical reasoning indirectly with a correlation coefficient of -1.13. Learning anxiety is a more dominant factor influencing mathematical reasoning abilities that is equal to $34.8 \%$, while learning styles only amount to $21.1 \%$. The results of this study expect the learning process that is designed to minimize learning anxiety and use appropriate learning styles so that it can improve mathematical reasoning abilities.
\end{abstract}

Keywords: learning anxiety, learning styles, mathematical reasoning abilities.

\section{PENDAHULUAN}

Kemampuan penalaran matematis merupakan salah satu standar kompetensi yang terdapat dalam standar proses pendidikan sehingga menjadi salah satu kemampuan yang harus dikembangkan.
Pentingnya kemampuan penalaran juga termuat dalam tujuan mata pelajaran matematika yaitu supaya siswa memiliki kemampuan bernalar dalam pola dan sifat, melakukan manipulasi matematika serta menggunakan pernyataan matematika dalam 
Ni Kadek Sudarti, I Made Candiasa, I Nyoman Sukajaya
Analisis Pengaruh Faktor Kecemasan Belajar Dan Gaya Belajar Terhadap Kemampuan Penalaran Matematis Siswa Kelas VIII di SMP Negeri Se-Kota Singaraja membuat kesimpulan, menyusun bukti atau menjelaskan gagasan [1]. Menurut Shurter dan Pierce istilah penalaran merupakan proses berfikir berdasarkan fakta dan sumber yang relevan untuk mencapai kesimpulan yang logis [2]. Definisi tersebut mengarah pada suatu pengertian yaitu penalaran sebagai suatu aktivitas penarikan kesimpulan yang ditandai dengan adanya proses berfikir.

Hingga saat ini, kemampuan siswa dalam bernalar khususnya pada pembelajaran matematika masih sangat terbatas. Ref. [3] mengungkapkan kemampuan penalaran siswa siswa masih tergolong rendah terlihat dari hasil penelitian menunjukkan bahwa $75 \%$ siswa memiliki nilai kemampuan penalaran dibawah KKM. Hal ini juga didukung oleh penelitian lain yang dilakukan oleh Ref. [4] mengenai penalaran matematis yang menyatakan bahwa kualitas kemampuan penalaran siswa masih rendah karena siswa belum mampu menyusun argumen dan menyimpulkan suatu jawaban. Rendahnya kemampuan penalaran matematis siswa dipengaruhi oleh banyak faktor. Beberapa faktor yang mempengaruhi kemampuan penalaran matematis siswa adalah gaya belajar dan kecemasan belajar siswa. Berbagai metode pembelajaran diterapkan tetapi jika siswa tidak siap secara mental dalam melaksanakan pembelajaran maka pembelajaran itu tidak akan mencapai tujuannya.

Dalam pembelajaran matematika, siswa umumnya beranggapan bahwa matematika adalah pelajaran yang sangat menakutkan dan paling sulit. Hal tersebut berpengaruh pada rendahnya kemampuan penalaran matematis siswa karena buruknya pikiran siswa terhadap matematika. Rasa takut dan pikiran buruk dalam belajar sering disamakan dengan kecemasan belajar. Kecemasan menurut Ref. [5] adalah perasaan tegang dan kekhawatiran yang biasanya timbul karena perasaan takut bahwa akan terjadi hal yang buruk. Selain kecemasan belajar, kemampuan siswa dalam bernalar juga ditentukan oleh tepat tidaknya gaya belajar yang digunakan dalam pembelajaran. Ref. [6] mendefinisikan gaya belajar sebagai kumpulan karakteristik seseorang dalam proses belajar mengajar yang membuat suatu pembelajaran efektif untuk beberapa orang dan tidak efektif untuk orang lain. Jika dalam proses pembelajaran siswa menggunakan gaya belajar yang tidak sesuai, maka siswa akan kesulitan dalam bernalar karena kurang nyaman dengan situasi belajar yang kurang sesuai. Ketidaknyamanan siswa dalam belajar juga dapat mempengaruhi kecemasan belajar siswa.

Berkaitan dengan pemaparan di atas, penelitian ini lebih berfokus pada bagaimana pengaruh langsung maupun tidak langsung antara kecemasan belajar dan gaya belajar terhadap kemampuan penalaran matematis siswa serta faktor mana yang paling berpengaruh terhadap kemampuan penalaran matematis siswa. Penelitian ini didukung oleh beberapa penelitian yang relevan yaitu penelitian oleh Ref. [7] yang menyimpulkan bahwa kecemasan belajar berpengaruh secara signifikan terhadap kemampuan penalaran matematis pada siswa SMP serta penelitian dari Ref. [8] yang menyatakan bahwa gaya belajar berpengaruh terhadap kemampuan penalaran matematis siswa.

\section{METODE PENELITIAN}

Jenis penelitian ini adalah penelitian ex post facto, yaitu sesuai dengan pengertiannya "dari apa dikerjakan setelah kenyataan", maka penelitian ini disebut sebagai penelitian sesudah kejadian untuk mengetahui apa penyebab terjadinya kejadian tersebut [9]. Penelitian ini menggunakan rancangan korelasional. Tujuan dari penelitian ini adalah untuk menganalisis pengaruh langsung maupun tidak langsung antara faktor kecemasan belajar dan gaya belajar terhadap kemampuan penalaran matematis siswa kelas VIII di SMP Negeri se-kota Singaraja. Model penelitian tampak pada Gambar 1 sebagai berikut. 
Ni Kadek Sudarti, I Made Candiasa, I Nyoman Sukajaya
Analisis Pengaruh Faktor Kecemasan Belajar Dan Gaya Belajar Terhadap Kemampuan Penalaran Matematis Siswa Kelas VIII di SMP Negeri Se-Kota Singaraja

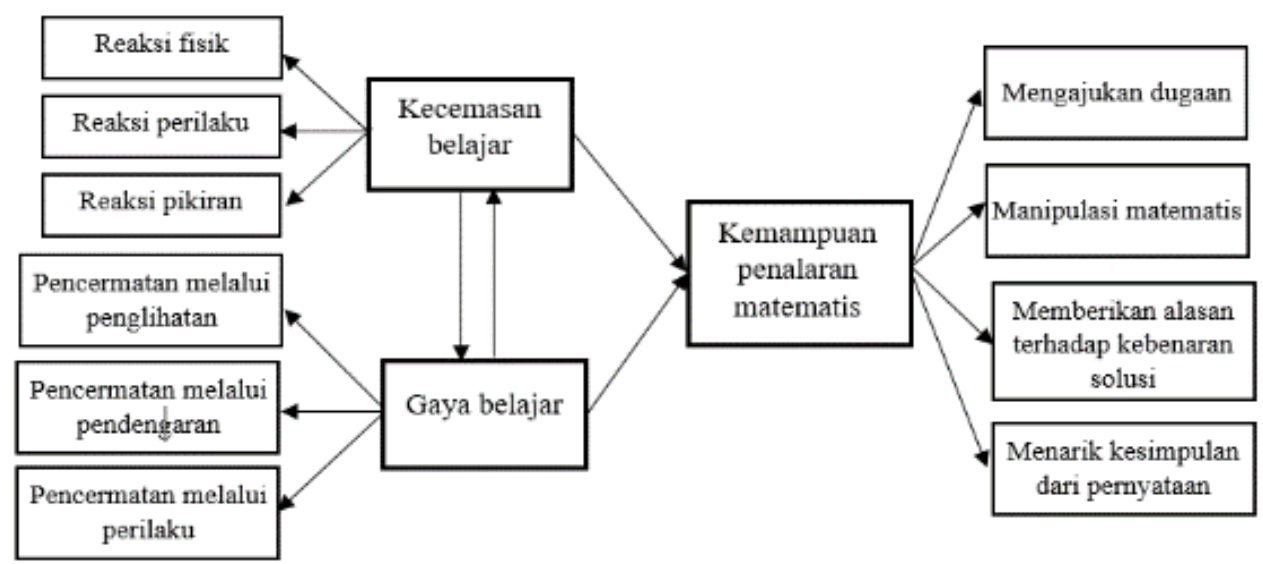

Gambar 1. Model Penelitian

Populasi dalam penelitian ini terdiri dari 2211 siswa kelas VIII SMP Negeri se-Kota Singaraja tahun ajaran 2019/2020. Pengambilan sampel dilakukan dengan teknik stratified random sampling untuk memilih tiga dari tujuh sekolah berdasarkan tingkatan rata-rata nilai matematika pada Ujian Nasional tahun 2019. Sekolah yang terpilih menjadi sampel penelitian yaitu SMPN 2 Singaraja, SMPN 4 Singaraja dan SMPN 6 Singaraja dengan jumlah sampel sebanyak 234 siswa.

Penelitian ini dilakukan di SMP Negeri seKota Singaraja, Kabupaten Buleleng, Bali. Waktu penyusunan rencana penelitian (proposal) sampai dengan penyusunan laporan penelitian dilakukan dari November 2019 sampai dengan Juni 2020.

Kemampuan penalaran matematis diukur menggunakan tes uraian. Sementara itu, kecemasan belajar dan gaya belajar diukur menggunakan kuesioner. Indikator kemampuan penalaran matematis berdasarkan Ref. [10] yaitu mengajukan dugaan, melakukan manipulasi matematis, memberikan alasan terhadap kebenaran solusi dan menarik kesimpulan dari pernyataan. Indikator kecemasan belajar berdasarkan Ref. [11] yaitu reaksi fisik, reaksi perilaku dan reaksi pikiran. Instrumen gaya belajar berdasarkan Ref. [12] yaitu pencermatan melalui penglihatan, pencermatan melalui pendengaran dan pencermatan melalui perilaku.

Sebelum digunakan, ketiga instrumen telah melalui proses validitas isi oleh ahli, dan dinyatakan layak untuk digunakan. Selanjutnya instrumen diujicobakan untuk mengetahui validitas

dan reliabilitas secara empirik. Berdasarkan hasil uji validitas dengan menggunakan rumus koefisien korelasi product moment diperoleh bahwa ketiga instrumen berkategori valid. Sementara itu, Hasil perhitungaan reliabilitas dengan menggunakan rumus construct reliability disajikan pada Tabel 1 berikut.

Table 1. Hasil Perhitungan Reliabilitas

\begin{tabular}{|c|c|c|c|}
\hline No. & Variabel & $\begin{array}{c}\text { Nilai } \\
C R\end{array}$ & Keterangan \\
\hline 1 & $\begin{array}{c}\text { Kemampuan } \\
\text { Penalaran } \\
\text { Matematis }\end{array}$ & 0,836 & Reliabiltas Tinggi \\
\hline 2 & $\begin{array}{c}\text { Kecemasan } \\
\text { Belajar }\end{array}$ & 0,834 & Reliabiltas Tinggi \\
\hline 3 & $\begin{array}{c}\text { Gaya } \\
\text { Belajar }\end{array}$ & 0,813 & Reliabiltas Tinggi \\
\hline
\end{tabular}

Data yang telah dikumpulkan selanjutnya dianalisis dengan menggunakan structural equation model (SEM). Dalam penelitian ini, SEM digunakan untuk menganalisis pengaruh langsung maupun tidak langsung antara faktor kecemasan belajar dan gaya belajar terhadap kemampuan penalaran matematis. Syarat utama menggunakan SEM adalah membangun suatu model hipotesis yang terdiri dari model struktural dan model pengukuran dalam bentuk diagram jalur yang ditunjukkan pada Gambar 2. Secara umum, langkah-langkah dalam analisis SEM adalah spesifikasi model, identifikasi model, 
Ni Kadek Sudarti, I Made Candiasa, I Nyoman Sukajaya
Analisis Pengaruh Faktor Kecemasan Belajar Dan Gaya Belajar Terhadap Kemampuan Penalaran Matematis Siswa Kelas VIII di SMP Negeri Se-Kota Singaraja estimasi model, evaluasi model dan interpretasi model. maksimum idealnya adalah 5. Sementara itu, masing-masing indikator pada variabel kecemasan belajar dan gaya belajar terdiri dari 8 butir

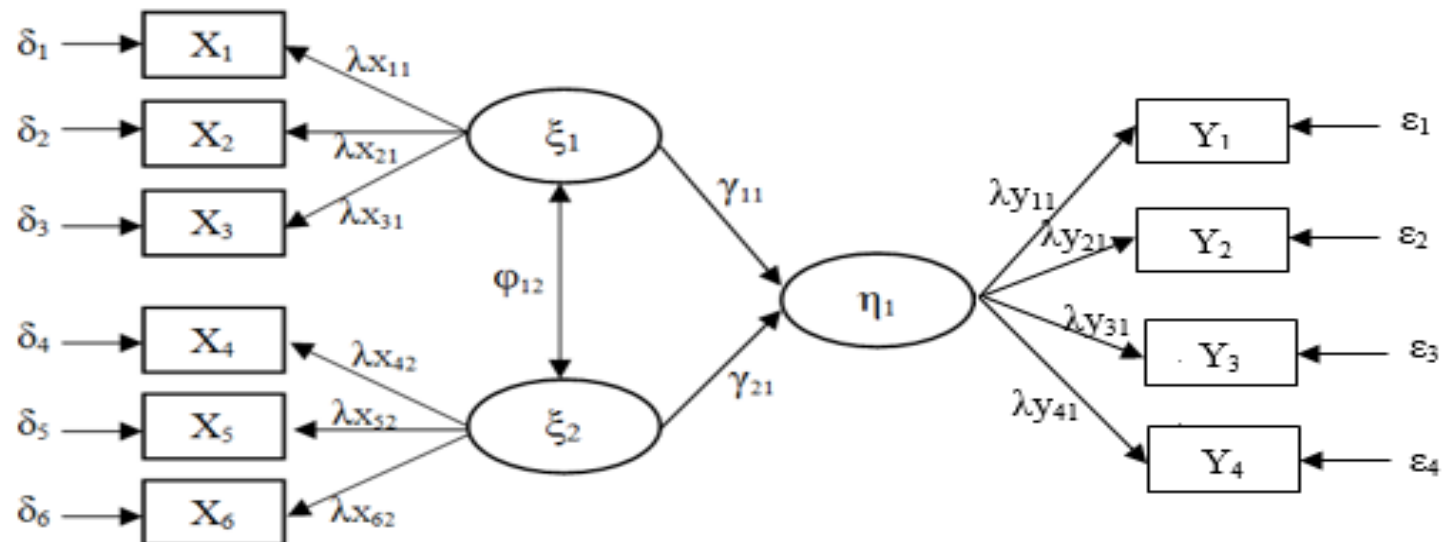

Gambar 2. Diagram Jalur

Keterangan:

$\xi_{1} \quad=$ Kecemasan belajar

$\xi_{2}=$ Gaya belajar

$\eta_{1}=$ Kemampuan penalaran matematis

$\mathrm{X}_{1} \quad=$ Reaksi fisik

$\mathrm{X}_{2} \quad=$ Reaksi perilaku

$\mathrm{X}_{3}=$ Reaksi pikiran

$\mathrm{X}_{4}=$ Pencermatan melalui penglihatan

$\mathrm{X}_{5}=$ Pencermatan melalui pendengaran

$\mathrm{X}_{6}=$ Pencermatan melalui perilaku

$\mathrm{Y}_{1} \quad$ Mengajukan dugaan

$\mathrm{Y}_{2}=$ Melakukan manipulasi matematis

$\mathrm{Y}_{3}=$ Memberikan alasan terhadap kebenaran solusi

$\mathrm{Y}_{4}=$ Menarik kesimpulan dari pernyataan

$\delta_{1}-\delta_{6}=$ Eror dari masing-masing indikator $\mathrm{X}$

$\varepsilon_{1}-\varepsilon_{4}=$ Eror dari masing-masing indikator $\mathrm{Y}$

$\lambda_{X}=$ Korelasi antara $\xi$ dengan indikator $\mathrm{X}$

$\lambda_{Y}=$ Korelasi antara $\eta$ dengan indikator $\mathrm{Y}$

$\varphi \quad=$ Korelasi antar $\xi$

$\gamma \quad=$ Korelasi antara $\xi$ dengan $\eta$

\section{HASIL DAN PEMBAHASAN}

Indikator mengajukan dugaan dan manipulasi matematis masing-masing terdiri dari 2 butir soal dengan skor maksimum per butirnya adalah 4 sehingga total skor maksimum idealnya adalah 8 . Sedangkan, indikator memberikan alasan terhadap kebenaran solusi dan indikator menarik kesimpulan dari pernyataan masing-masing terdiri dari 1 butir soal dengan skor maksimum 5 sehingga total skor pernyataan dengan skor maksimum 5 sehingga total skor maksimum idealnya adalah 40. Secara keseluruhan deskripsi masing-masing variabel per indikator disajikan pada Tabel 2.

Tabel 2. Nilai Rata-rata Indikator

\begin{tabular}{|c|c|c|}
\hline Indikator & $\begin{array}{l}\text { Rata- } \\
\text { rata }\end{array}$ & Kategori \\
\hline Mengajukan dugaan & 5,91 & Sangat tinggi \\
\hline $\begin{array}{l}\text { Manipulasi } \\
\text { matematis }\end{array}$ & 5,70 & Tinggi \\
\hline $\begin{array}{l}\text { Memberikan alasan } \\
\text { terhadap kebenaran } \\
\text { solusi }\end{array}$ & 3,11 & Cukup \\
\hline $\begin{array}{l}\text { Menarik kesimpulan } \\
\text { dari pernyataan }\end{array}$ & 2,92 & Cukup \\
\hline Reaksi fisik & 23,46 & Cukup \\
\hline Reaksi perilaku & 23,53 & Cukup \\
\hline Reaksi pikiran & 23,47 & Cukup \\
\hline $\begin{array}{l}\text { Pencermatan melalui } \\
\text { penglihatan }\end{array}$ & 23,04 & Cukup \\
\hline $\begin{array}{l}\text { Pencermatan melalui } \\
\text { pendengaran }\end{array}$ & 24,23 & Cukup \\
\hline $\begin{array}{l}\text { Pencermatan melalui } \\
\text { perilaku }\end{array}$ & 25,67 & Cukup \\
\hline
\end{tabular}

Data yang telah dikumpulkan dianalisis lebih lanjut menggunakan aplikasi Lisrel 9.20 sebagai alat bantu untuk mempermudah proses perhitungan yang menganalisis SEM secara bertahap. 
Ni Kadek Sudarti, I Made Candiasa, I Nyoman Sukajaya

Spesifikasi model merupakan langkah awal dalam analisis SEM. Pada tahap ini peneliti mendeskripsikan model penelitian pada Gambar 2 sebagai berikut.

a. Pengaruh kecemasan belajar terhadap kemampuan penalaran matematis direfleksikan oleh variabel siap reaksi fisik, reaksi perilaku dan reaksi pikiran.

b. Pengaruh gaya belajar terhadap kemampuan penalaran matematis direfleksikan oleh variabel pencermatan melalui penglihatan, pencermatan melalui pendengaran dan pencermatan melalui perilaku.

c. Kemampuan penalaran matematis yang dipengaruhi oleh kecemasan belajar dan gaya belajar direfleksikan oleh variabel mengajukan dugaan, melakukan manipulasi matematis, memberikan alasan terhadap kebenaran solusi dan menarik kesimpulan dari pernyataan.

Sebelum dilanjutkan ke tahap estimasi, terlebih dahulu dilakukan identifikasi model untuk menentukan apakah model yang dibangun memperoleh nilai yang unik. Berdasarkan perhitungan diperoleh nilai $\mathrm{df}=32>0$ maka dapat dikatakan bahwa model over identified, artinya parameter yang ada pada model dapat diestimasi dengan data yang dikumpulkan.

Tahapan selanjutnya setelah identifikasi model yaitu menentukan estimasi model yang digunakan. Hasil uji normalitas univariat dan multivariat dapat dilihat pada Tabel 3 dan Tabel 4 berikut.

Tabel 3. Uji Normalitas Univariat

\begin{tabular}{ccc}
\hline \multirow{2}{*}{ Indikator } & \multicolumn{2}{c}{ Skewness dan Kurtosis } \\
\cline { 2 - 3 } & Chi-Square & P-Value \\
\hline $\mathbf{X}_{\mathbf{1}}$ & 0,001 & 0,999 \\
$\mathbf{X}_{\mathbf{2}}$ & 0,011 & 0,994 \\
$\mathbf{X}_{\mathbf{3}}$ & 0,099 & 0,952 \\
$\mathbf{X}_{\mathbf{4}}$ & 0,052 & 0,974 \\
$\mathbf{X}_{\mathbf{5}}$ & 0,117 & 0,943 \\
$\mathbf{X}_{\mathbf{6}}$ & 0,019 & 0,990 \\
$\mathbf{Y}_{\mathbf{1}}$ & 1,957 & 0,376
\end{tabular}

Analisis Pengaruh Faktor Kecemasan Belajar Dan Gaya Belajar Terhadap Kemampuan Penalaran Matematis Siswa Kelas VIII di SMP Negeri Se-Kota Singaraja

\begin{tabular}{ccc}
\hline \multirow{2}{*}{ Indikator } & \multicolumn{2}{c}{ Skewness dan Kurtosis } \\
\cline { 2 - 3 } & Chi-Square & P-Value \\
\hline $\mathbf{Y}_{\mathbf{2}}$ & 2,231 & 0,328 \\
$\mathbf{Y}_{\mathbf{3}}$ & 1,853 & 0,396 \\
$\mathbf{Y}_{\mathbf{4}}$ & 5,407 & 0,067 \\
\hline
\end{tabular}

Tabel 4. Uji Normalitas Multivariat

\begin{tabular}{cll}
\hline \multirow{2}{*}{ Value } & \multicolumn{2}{c}{ Skewness dan Kurtosis } \\
\cline { 2 - 3 } & Chi-Square & P-Value \\
\hline 8,576 & 31,386 & 0,001 \\
\hline
\end{tabular}

Berdasarkan Tabel 3 nilai p-value untuk Skewness dan Kurtosis pada setiap indikator lebih dari 0,05, sehingga asumsi normalitas univariat terpenuhi. Sementara itu, berdasarkan Tabel 4 nilai p-value untuk Skewness dan Kurtosis kurang dari 0,5 yang artinya data di atas tidak memenuhi asumsi normalitas multivariate. Estimasi yang digunakan dalam model ini adalah estimasi Maximum Likelihood, dengan mengkoreksi standart error dan beberapa goodness of fit indices yang terjadi akibat ketidaknormalan data.

Setelah estimasi model, selanjutnya dilakukan evaluasi model. Hasil measurement factor dengan menggunakan aplikasi LISREL 9.20 ditunjukkan pada Gambar 3 dan Gambar 4 berikut.

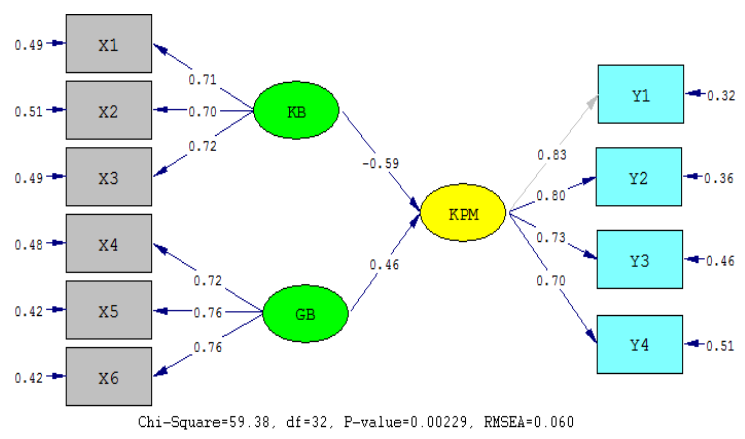

Gambar 3. Full Model (Standardized) 
Ni Kadek Sudarti, I Made Candiasa, I Nyoman Sukajaya

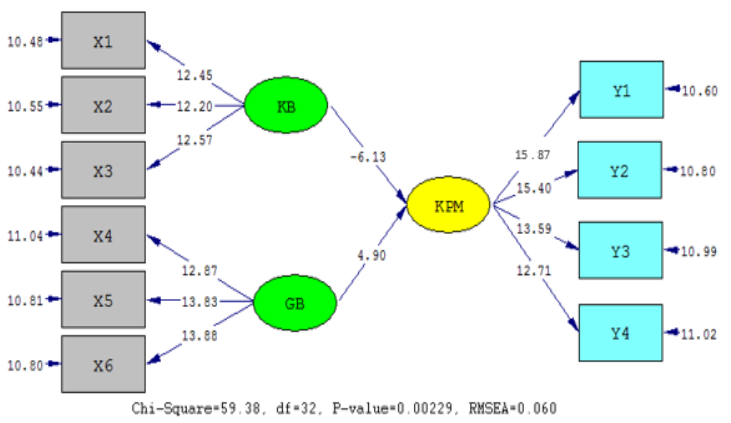

Gambar 4. Full Model ( $t$-value)

Evaluasi model pengukuran dilakukan dengan uji validitas dan reliabilitas konstruk. Uji validitas konstruk terdiri dari uji validitas konvergen dan discriminant. Uji validitas konvergen dilihat dari nilai loading faktor $>0,7$ dan nilai $\mathrm{t}$ hitung $>\mathrm{t}$ tabel untuk setiap indikator. Uji validitas discriminant dilihat dari nilai Average Variance Extacted (AVE) $>0,5$ pada setiap konstruk laten. Uji reliabilitas konstruk dilihat dari nilai Construct Reliability (CR) $>0,7$ Ref. [6] Hasil evaluasi model pengukuran berdasarkan Gambar 3 dan Gambar 4 di atas dapat dilihat pada Tabel 5 berikut.

Tabel 5. Hasil Uji Validitas dan Reliabilitas Konstruk

\begin{tabular}{ccccc}
\hline Indikator & $\begin{array}{c}\text { Faktor } \\
\text { Loading }\end{array}$ & Error & $\mathbf{R}^{2}$ & $\begin{array}{c}\mathbf{t} \\
\text { hitung }\end{array}$ \\
\hline $\mathrm{Y}_{1}$ & 0,83 & 0,32 & 0,68 & 15,87 \\
$\mathrm{Y}_{2}$ & 0,80 & 0,36 & 0,64 & 15,40 \\
$\mathrm{Y}_{3}$ & 0,73 & 0,46 & 0,54 & 13,59 \\
$\mathrm{Y}_{4}$ & 0,70 & 0,51 & 0,49 & 12,71 \\
$\mathrm{AVE}$ & & & 0,588 & \\
$\mathrm{CR}$ & & & 0,850 & \\
$\mathrm{X}_{1}$ & 0,71 & 0,49 & 0,51 & 12,45 \\
$\mathrm{X}_{2}$ & 0,70 & 0,51 & 0,49 & 12,20 \\
$\mathrm{X}_{3}$ & 0,72 & 0,49 & 0,51 & 12,57 \\
$\mathrm{AVE}$ & & & 0,504 & \\
$\mathrm{CR}$ & & & 0,753 & \\
$\mathrm{X}_{4}$ & 0,72 & 0,48 & 0,52 & 12,87 \\
& & & &
\end{tabular}

Analisis Pengaruh Faktor Kecemasan Belajar Dan Gaya Belajar Terhadap Kemampuan Penalaran Matematis Siswa Kelas VIII di SMP Negeri Se-Kota Singaraja

\begin{tabular}{ccccc}
\hline Indikator & $\begin{array}{c}\text { Faktor } \\
\text { Loading }\end{array}$ & Error & $\mathbf{R}^{\mathbf{2}}$ & $\begin{array}{c}\mathbf{t} \\
\text { hitung }\end{array}$ \\
\hline $\mathrm{X}_{5}$ & 0,76 & 0,42 & 0,58 & 13,83 \\
$\mathrm{X}_{6}$ & 0,76 & 0,42 & 0,58 & 13,88 \\
$\mathrm{AVE}$ & & & 0,559 & \\
$\mathrm{CR}$ & & & 0,792 & \\
\hline
\end{tabular}

Berdasarkan Tabel 5 di atas, tampak bahwa nilai faktor loading dari masing-masing indikator lebih dari 0,7 , nilai $t_{\text {hitung }}$ pada setiap indikator lebih dari $\mathrm{t}_{\text {tabel }}=1,97$ serta nilai AVE (Average Variance Extacted) lebih dari 0,5 sehingga model dinyatakan valid. Selain itu, ditunjukkan pula bahwa nilai CR ( Construct Reliability) lebih dari 0,7 sehingga model dinyatakan reliabel.

Sementara itu, Evaluasi model struktural dilakukan dengan analisis Goodness of Fit dari full model SEM yang ditunjukkan pada Tabel 6 berikut.

Tabel 6. Analisis Goodness of Fit

\begin{tabular}{cccl}
\hline $\begin{array}{c}\text { Goodness } \\
\text { of Fit }\end{array}$ & Nilai & $\begin{array}{c}\text { Cutt-Off } \\
\text { Value }\end{array}$ & Keterangan \\
\hline GFI & 0,954 & $>0,90$ & Model fit \\
RMSEA & 0,061 & $0,05-0,08$ & Model fit \\
AGFI & 0,921 & $\geq 0,90$ & Model fit \\
NFI & 0,965 & $\geq 0,90$ & Model fit \\
CFI & 0,983 & $\geq 0,90$ & Model fit \\
IFI & 0,983 & $\geq 0,90$ & Model fit \\
RFI & 0,950 & $\geq 0,90$ & Model fit \\
PNFI & 0,686 & $\geq 0,90$ & Model fit \\
PGFI & 0,555 & $0,05-0,08$ & Model fit \\
\hline
\end{tabular}

Menurut Ref. [13] penggunaan 4-5 kriteria goodness of fit dianggap sudah cukup untuk menilai kelayakan suatu model. Dengan melihat empat ukuran (GFI, RMSEA, AGFI, dan PGFI), maka model tersebut cukup fit dengan data. Untuk itu model penelitian bisa diterima, sehingga dapat dikatakan bahwa kecemasan belajar dan gaya belajar 
Ni Kadek Sudarti, I Made Candiasa, I Nyoman Sukajaya
Analisis Pengaruh Faktor Kecemasan Belajar Dan Gaya Belajar Terhadap Kemampuan Penalaran Matematis Siswa Kelas VIII di SMP Negeri Se-Kota Singaraja secara bersama-sama berpengaruh signifikan terhadap kemampuan penalaran matematis.

Setelah mengevaluasi model, tahap terakhir dalam SEM yaitu interpretasi model. Hasil penelitian dengan menggunakan analisis SEM diperoleh pengaruh langsung kecemasan belajar dan gaya belajar terhadap kemampuan penalaran matematis berturut-turut adalah $-0,59$ yang berarti memiliki pengaruh kuat dan 0,46 yang berarti memiliki pengaruh cukup kuat. Nilai negatif pada pengaruh langsung kecemasan belajar terhadap kemampuan penalaran matematis memberi makna bahwa hubungan yang terjadi berbanding terbalik. Semakin tinggi tingkat kecemasan belajar siswa, maka kemampuan siswa dalam bernalar akan semakin rendah. Sementara itu, nilai positif pada pengaruh langsung gaya belajar terhadap kemampuan penalaran matematis memberi makna bahwa hubungan yang terjadi sebanding. Semakin tinggi tingkat gaya belajar siswa, maka kemampuan siswa dalam bernalar juga akan semakin tinggi. Nilai thitung yang diperoleh pada variabel kecemasan belajar sebesar 6,13 dan nilai thitung yang diperoleh pada variabel gaya belajar sebesar 4,90, sedangkan nilai t tabel pada derajat bebas 234 adalah 1,97. Nilai $t_{\text {hitung }}$ yang lebih besar dari pada $t_{\text {tabel }}$ menunjukkan bahwa terdapat pengaruh signifikan dari kecemasan belajar ataupun dari gaya belajar terhadap kemampuan penalaran matematis. Hasil analisis SEM juga menunjukkan bahwa terdapat pengaruh tidak langsung antara kecemasan belajar dan gaya belajar terhadap kemampuan penalaran matematis. Besarnya pengaruh tidak langsung dari kecemasan belajar dan gaya belajar terhadap kemampuan penalaran matematis adalah $-1,13$ yang berarti memiliki pengaruh sangat kuat. Nilai negatif pada pengaruh tersebut memberi makna bahwa hubungan yang terjadi berbanding terbalik. Semakin tinggi tingkat kecemasan belajar siswa, maka gaya belajar siswa akan semakin rendah dan menyebabkan rendahnya kemampuan penalaran matematis. Begitu juga sebaliknya, semakin tinggi tingkat gaya belajar siswa, maka kecemasan siswa akan semakin rendah sehingga kemampuan penalaran matematis siswa akan semakin tinggi. Nilai thitung yang diperoleh pada pengaruh tidak langsung tersebut adalah sebesar 42,22 , sedangkan nilai $t_{\text {tabel }}$ pada derajat bebas 234 adalah 1,97. Nilai thitung yang lebih besar dari pada ttabel menyatakan bahwa terdapat pengaruh tidak langsung yang signifikan antara kecemasan belajar dan gaya belajar terhadap kemampuan penalaran matematis. Faktor kecemasan belajar lebih dominan mempengaruhi kemampuan penalaran matematis. Hal ini dapat terlihat dari nilai koefisien determinasi. Nilai koefisien determinasi dari kecemasan belajar sebesar 0,35 yang berarti kecemasan belajar memberikan pengaruh sebesar $35 \%$ terhadap kemampuan penalaran matematis, sedangkan gaya belajar hanya memberikan pengaruh sebesar $21,2 \%$ terhadap kemampuan penalaran matematis.

\section{KESIMPULAN}

Berdasarkan hasil penelitian dapat disimpulkan bahwa terdapat pengaruh langsung dari kecemasan belajar dan gaya belajar terhadap kemampuan penalaran matematis dengan besarnya korelasi berturut-turut adalah $-0,59$ yang berarti memiliki pengaruh kuat dan 0,46 yang berarti memiliki pengaruh cukup kuat. Hasil analisis juga menunjukkan bahwa terdapat pengaruh tidak langsung antara kecemasan belajar dan gaya belajar terhadap kemampuan penalaran matematis dengan korelasi sebesar $-1,13$ yang berarti memiliki pengaruh sangat kuat. Nilai negatif pada pengaruh tersebut memberi makna bahwa hubungan yang terjadi berbanding terbalik. Semakin tinggi tingkat kecemasan belajar siswa, maka gaya belajar siswa akan semakin rendah dan menyebabkan rendahnya kemampuan penalaran matematis. Begitu juga sebaliknya, semakin tinggi tingkat gaya belajar siswa, maka kecemasan siswa akan semakin rendah sehingga kemampuan penalaran matematis siswa akan semakin tinggi. Dilihat dari nilai koefisien determinasi, faktor kecemasan belajar lebih dominan mempengaruhi kemampuan penalaran matematis. Nilai koefisien determinasi dari kecemasan belajar sebesar 0,35 yang berarti kecemasan belajar memberikan pengaruh sebesar $35 \%$ terhadap kemampuan penalaran matematis, sedangkan gaya belajar hanya memberikan pengaruh sebesar $21,2 \%$ terhadap kemampuan penalaran matematis. Hasil penelitian ini mengharapkan kecemasan belajar siswa diperhatikan karena faktor inilah yang memberikan kontribusi besar terhadap meningkatkan kemampuan penalaran matematis siswa. 
Ni Kadek Sudarti, I Made Candiasa, I Nyoman Sukajaya
Analisis Pengaruh Faktor Kecemasan Belajar Dan Gaya Belajar Terhadap Kemampuan Penalaran Matematis Siswa Kelas VIII di SMP Negeri Se-Kota Singaraja

\section{DAFTAR PUSTAKA}

[1] Peraturan Mentri Pendidikan Nasional Republik Indonesia Nomor 20 Tahun 2006

[2] Y. Purnamasari, "Pengaruh Model Pembelajaran Kooperatif Tipe Teams Games Tournament (TGT) Terhadap Kemandirian Belajar Dan Peningkatan Kemampuan Penalaran Dan Koneksi Matematik Peserta Didik SMPN 1 Kota Tasikmalaya," J. Pendidik. dan Kegur., vol. 8, no. 2, pp. 126143, 2014.

[3] A. Gaza., N. D. Anisa., A. Padillah., N. Adi., B. Martin. "Analisis Kemampuan Penalaran dan Self Confience Siswa SMA pada Materi Peluang". Jurnal on Education, vol. 1(1), pp. 14-21, 2018.

[4] L. Jelita., R. Zulkarnaen. "Studi Kasus Kemampuan Penalaran Matematis Siswa Kelas VIII dalam Menyelesaikan Soal TIMSS. Matematika". Sesiomadika 2019: Unpublishes, 2019.

[5] Depkes RI. "Peraturan Menteri Kesehatan RI No. 416/Menkes/Per/IX/1990", Jakarta, 1990.

[6] Sugihartono, et. al. (2007). Psikologi Pendidikan. Yogyakarta: UNY Press.

[7] R. Wijaya. "Pengaruh Kecemasan Belajar dan Gender Terhadap Kemampuan Penalaran Adaptif Matematika Siswa SMP Negeri 2 Kendari". Jurnal Pendidikan, 2(8), 107-114 Jurnal Pendidikan. vol. 2(8), pp. 107-114, 2019.

[8] S. Deviana. "Pengaruh Gaya dan Motivasi Belajar Terhadap Kemampuan Penalaran Matematis". Jurnal Pendidikan. vol. 2(8), pp. 107-114, 2019.

[9] Sukardi. Metodologi Penelitian Pendidikan. Jakarta: PT Bumi Aksara, 2012.

[10] TIM PPPG Matematika. Materi Pembinaan Matematika SMP. Yogyakarta: Depdikbud, 2007

[11] J. S. Nevid. Psikologi Abnormal. Jakarta: Erlangga.Peraturan Mentri Pendidikan
Nasional Republik Indonesia Nomor 20 Tahun 2006, 2005.

[12] B. DePorter \& M. Hernacki. Membiasakan Belajar Nyaman dan Menyenangkan. Bandung: Kaifa, 2000

[13] Hair, et. al. Multivariate Data Analysis. Englewood Cliffs, NJ: Prentice Hall, 2006

[13] Sugihartono, et. al. Psikologi Pendidikan. Yogyakarta: UNY Press, 2007. 